\title{
Agro-Morphological and Genetic Diversity Studies in Rice (Oryza Sativa L.) Germplasm Using Microsatellite Markers
}

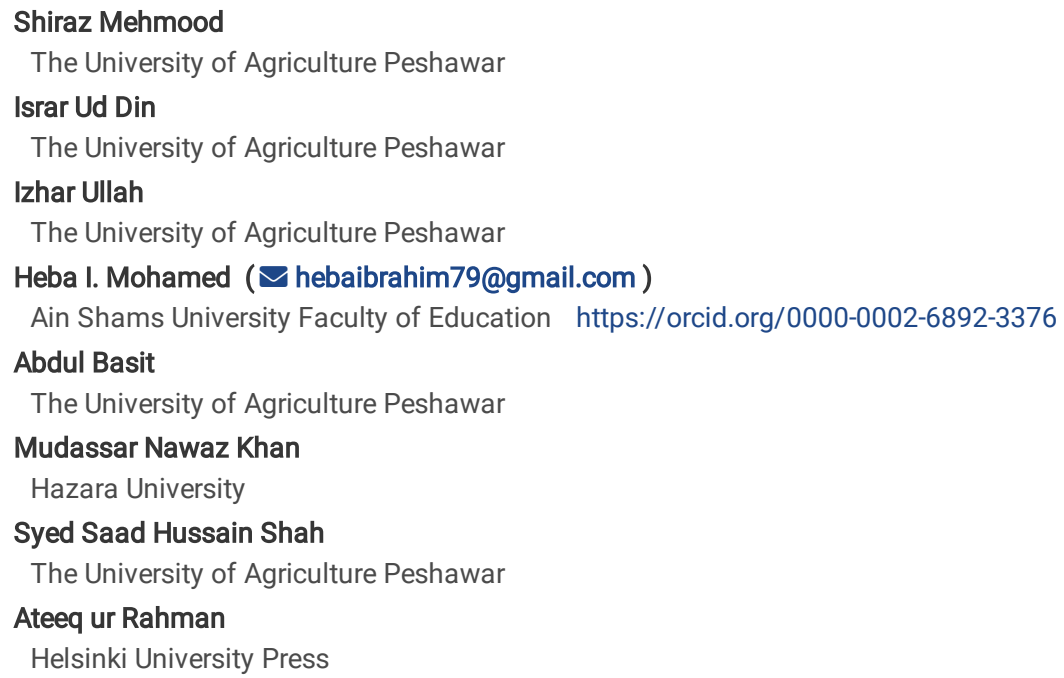




\section{Abstract}

Knowledge of the genetic diversity and population structure of germplasm collections is an important foundation for crop improvement. Rice production across a broad range of rice-growing environments results in a diverse array of local rice varieties. Many rice varieties have been lost as a result of biodiversity loss and are now grown in Pakistan. To protect the biodiversity of rice varieties, an experiment was carried out to check the genetic and morphological variations between 8 exotic and 7 local rice genotypes, using 5 different SSR markers, i.e, RM3, RM259, RM341, RM520, and RM11943. The analysis of morphological and quality traits of rice observed significant variation across genotypes. The results revealed that genotype Irri-Pak attained the highest plant height and primary branch plant-1, while genotype Mushkan produced a higher number of productive tillers and obtained a higher fertility factor (\%). Similarly, the highest value for panicle length was observed for genotype Faker-e-Malakand, 1000-grains weight in genotype Calmochi, and maximum days to maturity was noticed in genotype Swati-2014. Moreover, the genotype Brio attained the highest value of stem diameter, while maximum seed length was noted in genotype Sug Dasi. The highest number of primary branches plant ${ }^{-1}$ in genotype Ibge-I and secondary branches plant- 1 in genotype Calmochi were noticed. A higher concentration of sodium and potassium was observed for the genotype Marte, while the genotype Muskan attained the maximum content of copper. Moreover, the highest concentration of iron in genotype Originario, zinc in genotype JP-5, and cadmium content were noticed in genotype Ibge. Similarly, the dendrogram analysis for quantitative parameters showed three clusters at $74.13 \%$ similarities. Whereas all the genotypes of European origin formed a separate cluster. A set of 5 SSR primers, covering four chromosomes, amplified a total of 14 alleles and showed $100 \%$ polymorphism with an average PIC value ranging from 0.39 to 0.91 . The UPGMA cluster analysis separated the 15 rice genotypes into 3 main groups based on $32.5 \%$ similarities and the highest genetic distance (45.1\%) was observed between two genotypes (Fakher-e-malakand and Musa), having different geographical origins. There was no genetic distance between genotype Marte and Brio, irrespective of having the same origin.

\section{Introduction}

Rice (Oryza sativa L) is a self-pollinated crop, belongs to the family Graminae and is the most important staple food grain that occupies one-fifth of the total land covered. (Chakravarthi and Naravaneni 2006). Rice originated in China about 10000 years ago and presently two species i.e. Oryza sativa L. (Asian Rice) and Oryza glabberrima L. (African rice) are cultivated around the world, which were independently domesticated from wild Asian rice, Oryza rufipogon and wild African rice, Oryza barthii respectively (Chang 1976; Oka 1988; Khush 1997; Cheng et al. 2003; Yamanaka et al. 2004). Rice is Pakistan's second most important cereal crop after wheat, and it is grown on an area of 2.3 million hectares with a net production of 5.5 million tons (Junaid and Ali, 2015 ). In the global market, Pakistan is one of the main exporters of aromatic rice. Pakistan's annual rice exports are approximately 0.84 million tons of aromatic basmati rice and 2.85 million tons of non-aromatic indica rice, yielding a total of Rs 69325 million to the Pakistani economy (Rabbani et al. 2010). Since 1970, Pakistan has been a major exporter of Basmati rice. Many landraces of Basmati grown in Pakistan have been eradicated as a result of the green revolution and the introduction of high-yielding semi-dwarf varieties. Many improved rice genotypes have been released by rice research institutions for cultivation in different geographic regions of Pakistan that have narrow genetic bases because of higher homozygosity (Rabbani et al. 2008).

In the loss of global biodiversity, many rice varieties have been missed in Pakistan. Therefore, it is not only important to protect the land race genotypes, but also very necessary to examine the gene pool element of aromatic rice for breeding purposes (Rabbani et al. 2008). The rice germplasm is a rich reservoir of useful genes that researchers can harness for rice improvement programs. Rice germplasm contains genetic variability, allowing for a wide range of crop improvements. Information on the genetic diversity within and among closely related crop varieties is essential for the rational use of genetic resources. It contributes to monitoring germplasm and can also be used to predict potential genetic gains (Mandel et al. 2011).

Rice is very significant staple food, therefore it's necessary to improve the nutritional quality to mitigate malnutrition for poor population across the world (Gregorio et al. 2000). With regard to micronutrients malnutrition, concentration should be given particularly to improve iron (Fe) and zinc (Zn) deficiency. Hence, germplasm evaluation is important for the identification of $\mathrm{Zn}$ and Fe rich accessions to utilize them being a genetic resource for the development of cultivars having nutritional quality followed by the facilitation of conventional breeding methods. Starch is key component and is almost $90 \%$ of the entire rice kernel weight (Shih 2003). Natural brown rice offers B-complex vitamins, mainly riboflavin, niacin, thiamin and also contains helpful antioxidants i.e. tocotrienols, oryzanols and tocopherols. And provide nourishment to skin, healthy assistance and nutrition to blood vessels (Lloyd et al. 2000). While milling and polishing destroy $67 \%$ of Vit $B_{3}, 80 \%$ of Vit $B_{1}, 90 \%$ of Vitamin $B_{6}, 50 \%$ of phosphorus, $50 \%$ of manganese, $60 \%$ of all dietary fibers, iron and essential fatty acids (Babu et al. 2009).

The classification of different rice varieties is very closely linked together into groups which need time for characterization and show ineffective diversity by enzymatic, morphological, and physio-chemical methods. The most appropriate and reliable method of molecular characterization is the use of DNA based markers (Sarao et al. 2010). DNA markers are less expensive, less naturally conditioned, fast, accurate, and reproducible with high authenticity and can be useful in identifying and registering plant varieties, seed quality and purity monitoring (Cirillo et al. 2009).

Molecular markers have been shown to be powerful instruments for assessing genetic variation and clarifying genetic relations between genotypes and within. Several molecular markers, such as RFLP, RAPD, SSRs, ISSR, AFLP, retrotransposon and SNPs, are now available for evaluation of molecular variability and diversity (Mohamed and Abdel-Hamid 2013; Mohamed and Abd-El Hameed 2014; Mohamed et al. 2018,2019; Ashry et al. 2018; Ghonaim et al. 2021).

Simple Sequence Repeats (SSR) markers have been widely used to evaluate the genetic variations and their associations with subspecies among the rice varieties and the advantages of allele specificity and co-dominance (Kobayashi et al. 2006, Chuan-Guang and Zhang 2010, Latif et al. 2011). Currently, SSR markers are used for molecular characterization, i.e. highly reproducible, reliable, co-dominant, scattered throughout the whole genome, variable, abundant and multiallelic in nature (Salgotra et al. 2015). SSRs microsatellite markers have become the best choice for a wide range of studies of evolution, genetics and population study on the basis of variation in the simple sequences of DNA repeats (Jarne and Lagoda 1996; Powell et al. 1996). Second generation genetic 
maps have evolved significantly in many species, including humans (Dib et al. 1996) and plants such as potatoes (Milbourne et al. 1998), wheat (Bryan et al. 1997; Röder et al. 1998), soyabean (Akkaya et al. 1995; Cregan et al. 1999) and maize (Chin et al. 1996; Taramino and Tingey 1996).

Keeping these views on the importance of microsatellite markers, an experiment was planned to evaluate the agro-morphological traits and genetic diversity of the rice genotypes using microsatellite markers.

\section{Material And Methods}

\section{Plant material and field evaluation of morphological traits}

The present study was executed at the division of Plant Tissue Culture, Genetic Resources \& Conservation, Institute of Biotechnology and Genetic Engineering, The University of Agriculture Peshawar during the kharif season 2019. The research was carried out on 8 exotic and 7 local short grain rice genotypes in a Randomized Complete Block Design with one factor (Genotypes) replicated five times (Table 1). All these genotypes were analyzed for morphological, agronomic, and genetic diversity. Rice seeds were soaked in $45 \mathrm{ml}$ of distilled water in $50 \mathrm{ml}$ falcon tubes and incubated at $26^{\circ} \mathrm{C}$ for $48 \mathrm{~h}$. Seeds were grown in pots in green house to establish seedling nurseries. The pots were checked regularly and watered as per requirements. After five weeks, the seedlings were shifted to the field (plot size of $6 \times 2.5 \mathrm{ft} 2$ ) and then transplanted to rows at a distance of $1 \mathrm{ft}$ apart. Young leaves were collected from 25 -day-old seedlings for DNA extraction and immediately stored at $-20^{\circ} \mathrm{C}$ until further analysis.

Table 1

List of local and exotic rice genotypes

\begin{tabular}{|lll|}
\hline NO & Genotype & Origin \\
\hline 1 & Swati-2014 & Pakistan \\
\hline 2 & Originario & Italy \\
\hline 3 & Brio & Italy \\
\hline 4 & Ibge-2 & China \\
\hline 5 & Onice & Italy \\
\hline 6 & Marte-4 & Italy \\
\hline 7 & Ibge-1 & Pakistan \\
\hline 8 & Musa-7 & Italy \\
\hline 9 & Mushkan-340 & Pakistan \\
\hline 10 & IIRI-Pak & Pakistan \\
\hline 11 & Begami/ JP-5 & Pakistan \\
\hline 12 & Calmochi & Italy \\
\hline 13 & Ibge-3 & China \\
\hline 14 & Fakher-e-malakand & Pakistan \\
\hline 15 & Sug-Dasi/DR-83 & Pakistan \\
\hline
\end{tabular}

\section{Agro-morphological traits}

Observations were recorded on plant height $(\mathrm{cm})$, panicle length $(\mathrm{cm})$, fertility factor $(\%)$, days to maturity, number of seed plant ${ }^{-1}$, number of productive tillers, 1000-grains weight, primary branches and secondary branches plant ${ }^{-1}$ of rice genotypes.

\section{Determination of mineral contents}

Similarly, the micronutrients and heavy metal contents in seed samples were measured after acid digestion as described by Benton et al. (1991). A dry seed sample ( $0.5 \mathrm{~g}$ ) was taken into a $50 \mathrm{ml}$ Pyrex flask and $10 \mathrm{ml}$ of nitric acid was added to it and the sample was kept overnight. Perchloric acid (4 ml) was added, and the mixture was heated on a hot plate until the appearance of white and clear fumes. Dilute the digestion with $100 \mathrm{ml}$ of distilled water in a volumetric flask up to the mark. Potassium and sodium were determined using a flame photometer, while the micronutrient content in the extract was determined using an atomic absorption spectrophotometer.

\section{DNA extraction and PCR amplification}

DNA extraction from rice seedlings was carried out with the CTAB method previously described by Doyle et al. (1987). A 0.5g leaf sample was crushed and powdered in liquid nitrogen.One $\mathrm{ml}$ of Cetyl Tri Methyl Ammonium Bromide (CTAB) buffer was added immediately and transferred to $2 \mathrm{ml}$ of Eppendorf tubes. The samples were incubated in a water bath at $60^{\circ} \mathrm{C}$ for $30 \mathrm{~min}$ and then vortexed. A centrifugation step was performed at $12000 \mathrm{rpm}$ for $15 \mathrm{minutes}$. After centrifugation, the upper layer was transferred to a new Eppendorf tube and $500 \mu$ l of Phenol, Chloroform and Isoamylalcohol solution (P:C: I, 25:24:1) was added, followed by centrifugation at $12000 \mathrm{rpm}$ for 12 minutes to separate the sample into distinct phases. The upper layer was taken and transferred to a new tube and $28 \mu \mathrm{l}$ of ice-cold $\mathrm{Na}$ acetate and $600 \mu \mathrm{l}$ of pre-cooled isopropanol were added for the DNA precipitation. The sample was centrifuged again at 
$12000 \mathrm{rpm}$ for $12 \mathrm{~min}$ and the supernatant was removed without affecting the pellet. The pellet was washed two times with $500 \mu \mathrm{l}$ of $70 \%$ ethanol. The ethanol was discarded, and the pellet was dried at room temperature. Then the DNA was treated for $1 \mathrm{hr}$ with 40 micro-gram RNase-A at $37^{\circ} \mathrm{C}$. The DNA pellet was suspended in a $50 \mu \mathrm{l} \mathrm{TE} \mathrm{buffer} \mathrm{(10Mm} \mathrm{Tris,} 1 \mathrm{mM}$ EDTA, PH 8). The overall genomic DNA concentration, quality and optical density were measured at a wavelength of $260 / 280 \mathrm{~nm}$ by Nano Drop for all the samples and the samples were stored at $-20^{\circ} \mathrm{C}$ for further analysis.

\section{Molecular characterization}

To study the genetic diversity among rice genotypes, five SSR markers were used covering 4 chromosomes as shown in Table 2.

Table 2

List of SSR primers and their sequences

\begin{tabular}{|c|c|c|c|c|c|}
\hline S. No & Primer & Primer sequence $\left(5^{\prime}-3^{\prime}\right)$ & Annealing temp $\left({ }^{\circ} \mathrm{C}\right)$ & Chr. No & Product Size \\
\hline $1 \mathrm{~F}$ & RM 3 & ACACTGTAGCGGCCACTG & $55^{\circ} \mathrm{C}$ & 6 & $118 \mathrm{bp}$ \\
\hline $1 \mathrm{R}$ & RM 3 & ССТССАСТGСТССАСАТСТT & & & \\
\hline $2 \mathrm{~F}$ & RM259 & TGGAGTTTGAGAGGAGGG & $55^{\circ} \mathrm{C}$ & 1 & $172 b p$ \\
\hline $2 \mathrm{R}$ & RM259 & CTTGTTGCATGGTGCCATGT & & & \\
\hline $3 F$ & RM341 & CAACAAACCTCAATCCGAGC & $57^{\circ} \mathrm{C}$ & 2 & 137bp \\
\hline $3 R$ & RM341 & СТССТСCCGАTСССААТС & & & \\
\hline $4 \mathrm{~F}$ & RM520 & AGGAGCAAGAAAAGTTCCCC & $55^{\circ} \mathrm{C}$ & 3 & $247 \mathrm{bp}$ \\
\hline $4 \mathrm{R}$ & RM520 & GCCAATGTGTGACGCAATAG & & & \\
\hline $5 F$ & RM11943 & CTTGTTCGAGGACGAAGATAGGG & $55^{\circ} \mathrm{C}$ & 1 & 77bp \\
\hline $5 R$ & RM11943 & CCAGTTTACCAGGGTCGAAACC & & & \\
\hline
\end{tabular}

\section{Polymerase Chain Reaction (PCR)}

The PCR reaction was performed as described by Prasad et al. (2000), with a small modification in the thermal profile. A $10 \mu$ PCR reaction contains $1 \mu$ l of template DNA, $2 \mu \mathrm{l}$ of SSR primer, $1.8 \mu \mathrm{l}$ of nuclease free water, $0.2 \mu \mathrm{l}$ of Taq polymerase and $5 \mu \mathrm{l}$ of master mix. PCR conditions for the amplification were set. The early denaturation step of $3 \mathrm{~min}$ at $94^{\circ} \mathrm{C}$ is followed by 35 cycles, each comprised of a denaturation 30 sec step at $94^{\circ} \mathrm{C}$, an annealing step of 45 sec at $55^{\circ} \mathrm{C}$ and an extension step of $45 \mathrm{sec}$ at $72^{\circ} \mathrm{C}$. The BIO-RAD T100 thermal cycler was used.

\section{Gel Electrophoresis}

The amplified PCR products were confirmed on a $2 \%$ Agarose gel, which was prepared in $1 \mathrm{X}$ TBE buffer and then melted in a microwave oven for 2 min and 2 $\mu \mathrm{l}$ of ethidium bromide was added. After cooling at room temperature for $20 \mathrm{~min}$, the gel was kept in the gel tank, the DNA ladder (50 bp) and the PCR product were loaded and ran for $45 \mathrm{~min}$ at $100 \mathrm{~V}$. After electrophoresis, the gel was stained with UV in a gel documentation system.

\section{Statistical analysis}

For statistical analysis, the amplified bands of the same size were marked as a single allele and of different size were scored as different alleles. The Simple Sequence Repeats (SSR) data was analyzed by Microsoft Excel and Pop Gene version 3.25. The alleles were marked as present or absent. Genetic diversity among genotypes was calculated using the Unweight Pair Group Method with Arithmetic Mean (UPGMA) procedure to construct a dendrogram using the Pop gene. Principal component analysis (PCA) was calculated by using XL Stat to simplify the complexity of the high-dimensional data while retaining the trends and patterns.

\section{Results}

\section{Morphological characterization}

Different morphological attributes were significantly influenced by different exotic and local genotypes of rice (Table 3 and Fig. 1). The taller plant was noticed for IRRI-Pak, followed by the genotype Sug-Desi $130 \mathrm{~cm}$, while a shorter plant was observed for the genotype Onice. Overall, the local varieties were taller than the exotic varieties. Maximum panicle length was observed for genotype Fakher-e-malakand and the highest fertility factor was noted for genotype Mushkan, while minimum panicle length and minimum fertility factor were observed for genotype Onice. Similarly, the highest number of productive tillers panicle ${ }^{-1}$ and number of seeds per panicle were produced by genotype Mushkan, while the lowest number of productive tillers panicle-1 was recorded for genotype Begami/JP-5, and the total number of seeds per panicle was noted for genotype Originario. Maximum days to maturity were taken by genotype Swati-2014 and minimum days to maturity were recorded for genotype Marte. The highest 1000 grain weight was noted for the genotype of Calmochi as compared to other genotypes. The genotype Sug-Dasi had the longest seed length, followed by Mushkan and Calmochi. Whereas genotypes Brio and Marte received minimum seed length. Among the 8 exotic and 7 local rice varieties, the maximum seed diameter was noted for genotype Brio and the minimum seed diameter was recorded for Musa and Mushkan respectively. The highest number of primary branches plant ${ }^{-1}$ for Ibge-l and secondary branches plant- 1 was produced by genotype Calmochi, while the lowest number of primary branches plant ${ }^{-1}$ was recorded for genotype Calmochi and secondary branches plant- 1 was observed for genotype Brio. 
Table 3

Mean performance of 15 rice genotypes for various morpho-yield traits in Peshawar during 2019 crop season.

\begin{tabular}{|c|c|c|c|c|c|c|c|c|c|}
\hline Genotypes & $\begin{array}{l}\text { Plant } \\
\text { height } \\
\text { (cm) }\end{array}$ & $\begin{array}{l}\text { Panicle } \\
\text { length } \\
\text { (cm) }\end{array}$ & $\begin{array}{l}\text { Fertility } \\
\text { factor } \\
(\%)\end{array}$ & $\begin{array}{l}\text { Days to } \\
\text { maturity } \\
\text { (no.) }\end{array}$ & $\begin{array}{l}\text { Total number of } \\
\text { seed plant }\end{array}$ & $\begin{array}{l}\text { No. of } \\
\text { productive } \\
\text { tillers }\end{array}$ & $\begin{array}{l}\text { 1000grain } \\
\text { weight }(\mathrm{g})\end{array}$ & $\begin{array}{l}\text { Primary } \\
\text { branches } \\
\text { plant }^{-1}\end{array}$ & $\begin{array}{l}\text { Secondary } \\
\text { branches plant }^{-} \\
1\end{array}$ \\
\hline $\begin{array}{l}\text { Swati- } \\
2014\end{array}$ & $85.2^{f}$ & 21.9 de & $93.55^{a b}$ & $126.8^{a}$ & $100.2^{e}$ & $38.2 \mathrm{c}$ & $26.9 \mathrm{de}$ & 10.2 ef & $18.4 \mathrm{fgh}$ \\
\hline $\begin{array}{l}\text { Fakher-e- } \\
\text { malakand }\end{array}$ & $104.8^{d}$ & $32.0^{\mathrm{a}}$ & $86.23^{\mathrm{de}}$ & $123.4^{\mathrm{ab}}$ & $188.8^{b}$ & $30.0^{d}$ & 25.4 ef & $8.0^{\mathrm{gf}}$ & $14.2^{\mathrm{hi}}$ \\
\hline Sug-dasi & $130.0^{b}$ & $26.1^{b}$ & $88.93^{\mathrm{cd}}$ & $122.4^{\mathrm{ab}}$ & 85.4 efg & $29.8^{d}$ & $21.7^{f}$ & $10.8 \mathrm{de}$ & 23.4 de \\
\hline Irri-pak & $151.6^{a}$ & $26.5^{b}$ & $87.91^{\mathrm{cd}}$ & $120.0 \mathrm{abc}$ & $187.2^{b}$ & $46.6^{b}$ & 24.4 ef & $12.2^{\mathrm{bcd}}$ & $14.0^{\mathrm{hi}}$ \\
\hline Calmochi & 98.6 de & $21.5^{\mathrm{de}}$ & 82.58 ghi & 118.0 abcd & $128.0^{\mathrm{cd}}$ & $27.4^{d}$ & $34.6^{\mathrm{a}}$ & $7.0^{\mathrm{h}}$ & $10.4^{i}$ \\
\hline$J p-5$ & $107.6^{d}$ & $26.6^{b}$ & $84.82^{\text {efgh }}$ & $118.0^{a b c d}$ & $126.0 \mathrm{~cd}$ & $13.6^{f}$ & $26.8^{\mathrm{de}}$ & 9.6 efg & $19.2^{\mathrm{efg}}$ \\
\hline Musa & $72.2^{\mathrm{g}}$ & $14.1^{\mathrm{gh}}$ & 86.52 def & $118.6^{\mathrm{abcd}}$ & 90.0 ef & 17.0 ef & $28.0^{\text {cde }}$ & $12.6^{b c}$ & 21.4 ef \\
\hline Ibge-3 & $87.8^{f}$ & $25.1^{b c}$ & 85.66 def & $118.0^{\mathrm{abcd}}$ & $186.0^{b}$ & 18.2 ef & $25.5^{\text {ef }}$ & 9.6 efg & $16.8^{\mathrm{gh}}$ \\
\hline Mushkan & $121.8 \mathrm{bc}$ & $23.3^{\mathrm{cd}}$ & $95.45^{a}$ & $117.0 \mathrm{abcd}$ & $218.6^{a}$ & $52.0^{a}$ & 25.1 ef & 11.0 cde & $33.8 \mathrm{a}$ \\
\hline Ibge-1 & $118.0^{c}$ & $25.1^{b c}$ & $90.72^{b c}$ & $117.0^{\mathrm{abcd}}$ & $145.0^{c}$ & $14.0^{f}$ & $22.1^{\text {ef }}$ & $14.4^{\mathrm{a}}$ & $28.4^{b c}$ \\
\hline Originario & $68.0^{\mathrm{gh}}$ & $16.1^{\mathrm{fg}}$ & $81.72^{\text {hij }}$ & $114.6^{\mathrm{bcd}}$ & $65.0^{\mathrm{g}}$ & $21.6^{\mathrm{e}}$ & $300 \mathrm{bcd}$ & $11.6^{\text {cde }}$ & $21.0^{\mathrm{ef}} \mathrm{g}$ \\
\hline Onice & $61.8^{h}$ & $13.1^{\mathrm{h}}$ & $75.61^{k}$ & $114.2^{\mathrm{bcd}}$ & $69.6^{\mathrm{fg}}$ & $21.6^{\mathrm{e}}$ & $31.4^{\mathrm{abc}}$ & 10.0 ef & $27.0^{\mathrm{cd}}$ \\
\hline Brio & $90.7^{\text {ef }}$ & $21.2^{\mathrm{de}}$ & $79.07^{j}$ & $112.0^{\mathrm{bcd}}$ & $146.0^{c}$ & $31.4^{d}$ & $33.01^{a b}$ & $12.2^{b c d}$ & $35.0^{a}$ \\
\hline Ibge-2 & $102.8^{d}$ & $20.2^{\mathrm{e}}$ & $81.14^{\mathrm{ij}}$ & $110.2^{\mathrm{cd}}$ & 107.6 de & $14.6^{f}$ & $27.6^{\text {cde }}$ & $13.2^{a b}$ & $32.8^{a b}$ \\
\hline Marte & $71.06^{\mathrm{g}}$ & $17.6^{f}$ & $84.13^{\text {fghi }}$ & $107.6^{d}$ & $125.4^{\mathrm{cd}}$ & $21.0^{\mathrm{e}}$ & $26.3^{d c}$ & $9.0^{\mathrm{fg}}$ & $12.0^{i}$ \\
\hline LSD $_{0.05}$ & 8.99 & 2.3 & 3.13 & 11.54 & 24.08 & 4.97 & 4.1 & 1.71 & 4.42 \\
\hline
\end{tabular}

\section{Quality attributes}

Different exotic and local genotypes significantly influenced data on rice quality attributes. The genotype Marte had the highest sodium and potassium concentrations, while Brio and Mushkan had the lowest sodium concentrations (Fig. 2a, b). The genotype Marte had the highest sodium and potassium concentrations, while Brio and Mushkan had the lowest sodium concentrations (Fig. 2a, b). The maximum copper content was noted for genotype Mushkan followed by genotype Brio. While the minimum concentration of copper was attained by genotype lbge-1 (Fig. 2c). Similarly, the genotype Originario attained a higher content of iron over other rice germplasms (Fig. 2d). The maximum concentration of zinc was noticed in JP-5 followed by Mushkan and Onice and the minimum concentration of zinc was observed in Originario (Fig. 2e). The highest concentration of cadmium was noted for genotype lbge-and the lowest concentration of cadmium was recorded in Swati-2014 (Fig. 2f).

\section{Morphological diversity}

On the basis of quantitative morphological traits, a dendrogram was constructed using XLSTAT software and Agglomerative Hierarchical Clustering (AHC). Based on morphological traits varieties were classified into three major groups at $14 \%$ dissimilarities. The group A included four varieties, i.e. Ibge-3, Faker-eMalakand, Mushkan and IRRI-Pak. Group B consisted of five varieties i.e., lbge-1, Ibge-2, JP-5, Swati-2014 and Sug-Dasi/DR-83, while other six varieties fall in group C i.e. Brio, Calmochi, Originario, Onice, Marte and Musa (Fig. 3).

\section{Principle Component Analysis (PCA)}

To determine the variability between rice germplasm on the basis of morphological traits, Principal Component Analysis (PCA) was performed using XLSTAT software. Observations of PCA for the first two principal components have Eigen values greater than 1 accounting for $74.13 \%$ of total variation (Fig. 5). The first and second component factors (F1) and factor (F2) were estimated to account for $54.94 \%$ and $19.19 \%$ of total variance, respectively (Fig. 4, 5). Except days to maturity all the traits vary together according to PCA1. These traits were total seeds and 1000 grain weight, while days to maturity showed a negative value. According to PCA2, other traits such as plant height, the number of productive tillers and panicle length vary. Similarly, in the PCA scattered plot, genotypes Originario, Musa, lbge-2 and Swati-2014 showed negative scores on both axes. Genotype Begami/Jp-5, lbge-1, Sug-Dasi and Mushkan displayed positive scores for the first two axes and showed negative scores for the second axis. Genotype Onice, Marte, Calmochi, and Brio displayed negative values for the first axis, while attaining a positive score for the second axis. Genotype ibge-3, FM, Irri-pak showed positive for both axis (Fig. 5). 


\section{Molecular Characterization}

Five SSR markers covering 4 chromosomes were used to characterize and evaluate genetic diversity among fifteen diverse rice genotypes. Based on SSR analysis of 5 microsatellite loci, a total of 14 alleles were detected using five pairs of SSR primers. The average polymorphism for all the markers observed was $100 \%$ (Table 4). A significant level of genetic variability for five microsatellite loci was detected among these fifteen rice genotypes.

Table 4

Shows polymorphic bands, number of band patterns and polymorphism of each marker between 15 rice genotypes.

\begin{tabular}{|llll|}
\hline Primers & Band Pattem & Polymorphic Bands & Polymorphism \% \\
\hline RM 3 & 3 & 3 & $100 \%$ \\
\hline RM 259 & 2 & 2 & $100 \%$ \\
RM 341 & 4 & 4 & $100 \%$ \\
\hline RM 520 & 3 & 3 & $100 \%$ \\
\hline RM 11943 & 2 & 2 & $100 \%$ \\
Total & 14 & 14 & $100 \%$ \\
\hline
\end{tabular}

\section{SSR Marker RM 3}

Among 15 different rice genotypes, amplified with 5 SSR primer pairs, we observed 15 allelic bands with 3 band patterns with a band size of $118-150$ bps. All the observed band patterns were polymorphic. The overall frequency scored for alleles A, B and C was $0.4000,0.3333$ and 0.1333 , respectively. The PIC value for RM 3 was found to be 0.64 (Fig. 6a).

\section{SSR Marker RM 259}

The 15 rice genotypes amplified with RM 259 showed 14 allelic bands with 2 band patterns with a band size of 172 bps. All the observed band patterns were polymorphic. The overall allelic frequency was scored for alleles A and B, which was 0.2143 and 0.5714 , respectively. The PIC value for RM 259 was found to be 0.39 (Fig. 6b).

\section{SSR Marker RM 341}

For RM341, we observed a total of 16 allelic bands with 4 band patterns among 15 rice genotypes. All the observed band patterns were polymorphic with a band size of $150-200 \mathrm{bps}$. The overall frequency shown by allele A, B, C, and allele D was $0.0714,0.2857,0.0714$ and 0.2143 respectively. The PIC value for RM 341 was found to be 0.83 (Fig. 6c).

\section{SSR Marker RM 520}

DNA fingerprinting of 15 rice genotypes using RM 520 primers produced a total of 15 allelic bands with 3 band patterns with a band size of $247-270 b p s$. All the observed band patterns were polymorphic. The overall allelic frequency recorded for allele A, B and allele $C$ was $0.0667,0.0667$ and 0.2667 , respectively. The PIC value for RM 520 was found to be 0.91 (Fig. 6d).

\section{SSR Marker RM 11943}

Molecular characterization of 15 rice genotypes by RM 11943 primers depicted 15 allelic bands with 2 band patterns with a band size of $77 b p s$. Both the band patterns were polymorphic. The overall allelic frequency scored for alleles A and B was 0.3333 and 0.2000 , respectively. The PIC value for RM 11943 was found to be 0.83 (Fig. 6e).

\section{Overall allelic frequency}

Genetic variability assessment of 15 rice genotypes produced a total of 14 allelic bands utilizing 5 SSR primers (Table 5). For RM3, the highest allelic frequency was shown by allele A (0.4000), followed by allele B (0.3333) and the lowest allelic frequency was recorded for allele C (0.1333). Using RM 259 , the highest frequency was recorded for allele B (0.5714), while the lowest frequency was noted for allele A (0.2143). Similarly, with RM 341 , maximum allelic frequency was obtained for allele $B(0.2857)$ followed by allele $D(0.2143)$, while minimum allelic frequency was noted for $A$ and $C$, i.e. 0.0714 . For RM 520 , the highest allelic frequency was noted for allele $\mathrm{C}(0.2667)$ and the lowest allelic frequency was noted for A and B, i.e. 0.0667. Moreover, RM 11943 displayed maximum allelic frequency for allele $A(0.3333)$, while minimum allelic frequency was noted for allele B $(0.2000)($ Table 6,7$)$. 
Table 5

Shows Overall allelic frequency.

\begin{tabular}{|lll|}
\hline Primer & Locus/Allele & Frequency \\
\hline RM 3 & A & 0.4000 \\
\hline RM 3 & B & 0.3333 \\
\hline RM 3 & C & 0.1333 \\
\hline RM259 & A & 0.2143 \\
\hline RM259 & B & 0.5714 \\
\hline RM 341 & A & 0.0714 \\
\hline RM 341 & B & 0.2857 \\
\hline RM 341 & C & 0.0714 \\
\hline RM 341 & D & 0.2143 \\
\hline RM 520 & A & 0.0667 \\
\hline RM 520 & B & 0.0667 \\
\hline RM 520 & C & 0.2667 \\
\hline RM11943 & A & 0.3333 \\
\hline RM11943 & B & 0.2000 \\
\hline
\end{tabular}

Table 6

Shows multi-populations Descriptive Statistics.

\begin{tabular}{|llllll|}
\hline Locus & $\mathrm{Na}$ & $\mathrm{Ne}$ & Obs. Hetro & Exp. Hetro & PIC value \\
\hline Primer RM259 & 2.0000 & 1.3902 & 0.0000 & 0.6032 & 0.391 \\
\hline Primer RM 11943 & 2.0000 & 1.7108 & 0.0000 & 0.6529 & 0.539 \\
\hline Primer RM341 & 4.0000 & 4.9000 & 0.1429 & 0.8254 & 0.833 \\
\hline Primer RM520 & 3.0000 & 2.1690 & 0.0000 & 0.7080 & 0.914 \\
\hline Primer RM 3 & 3.0000 & 2.2609 & 0.0000 & 0.7172 & 0.642 \\
\hline * Na = Observed number of alleles & & & \\
\hline * Ne= Effective number of alleles [Kimura and Crow (1964)] & \\
\hline * PIC = Polymorphic information content [Botstein et al (1980)] & \\
\hline
\end{tabular}

Table 7

Overall allele frequency

\begin{tabular}{|llllll|}
\hline Allele/locus & Primer RM259 & Primer RM11943 & Primer RM341 & Primer RM520 & Primer RM3 \\
\hline A & 0.2143 & 0.3333 & 0.0714 & 0.0667 & 0.4000 \\
\hline B & 0.5714 & 0.2000 & 0.2857 & 0.0667 & 0.3333 \\
\hline C & & & 0.0714 & 0.2667 & 0.1333 \\
\hline D & & & 0.2143 & & \\
\hline
\end{tabular}

\section{Genetic relationship of the rice germplasm}

The genetic relationship was assessed in this study by creating a dendrogram with the Unweight Pair Group Method with Arithmetic Means (UPGMA) cluster analysis, which was based on Nei's Genetic distance modified from the NEIGHBOR procedure of PHYLIP Version 3.5 Pop-Gene software. Based on the dendrogram results, all rice genotypes were divided into three main groups with a $32.5 \%$ similarity. There were seven varieties in group $A$, i.e. FM, DR-83, Mushkan, Ibge-3, Calmochi, Irri-pak and JP-5. In group B, there were five varieties, i.e. Onice, Brio, Marte, Swati-2014 and Originario. Musa, Ibge-2, and Ibge-3 were assigned to group $\mathrm{C}$. The rice genotypes used for genetic distances and grouping arrangements are presented in Table 8 and Fig. 7. The maximum genetic distances were noted for the genotypes, Faker Malakand and Musa, i.e. $45.1 \%$, as the origin of the genotypes is different. While the minimum genetic distance, i.e. $12.0 \%$ was shown by genotype, Marte and Once, where both are from the same origin. Furthermore, there was no genetic distance between genotype Marte and Brio, i.e. $0 \%$ had the same origin (Table 8). 
Table 8

Estimation the genetic diversity among 8 exotic and 7 local rice germplasm with five SSR primer sets.

\begin{tabular}{|c|c|c|c|c|c|c|c|c|c|c|c|c|c|c|c|}
\hline & $\begin{array}{l}\text { Swati- } \\
2014\end{array}$ & Originario & Brio & $\begin{array}{l}\text { IBGE- } \\
2\end{array}$ & Onice & $\begin{array}{l}\text { Marte- } \\
4\end{array}$ & $\begin{array}{l}\text { IBGE- } \\
1\end{array}$ & Musa & $\begin{array}{l}\text { Mushkan- } \\
340\end{array}$ & $\begin{array}{l}\text { IIRI- } \\
\text { Pak }\end{array}$ & $\begin{array}{l}\text { JP- } \\
5\end{array}$ & Calmochi & $\begin{array}{l}\text { IBGE- } \\
3\end{array}$ & $\begin{array}{l}\text { Faker } \\
\text { Malakand }\end{array}$ & $\begin{array}{l}\text { Su } \\
\text { DE }\end{array}$ \\
\hline $\begin{array}{l}\text { Swati- } \\
2014\end{array}$ & 0.0 & & & & & & & & & & & & & & \\
\hline Originario & 13.5 & 0.0 & & & & & & & & & & & & & \\
\hline Brio & 13.5 & 17.0 & 0.0 & & & & & & & & & & & & \\
\hline IBGE-2 & 19.1 & 17.0 & 24.1 & 0.0 & & & & & & & & & & & \\
\hline Onice & 19.1 & 20.9 & 12.0 & 20.9 & 0.0 & & & & & & & & & & \\
\hline Marte-4 & 13.5 & 17.0 & 0.0 & 24.1 & 12.0 & 0.0 & & & & & & & & & \\
\hline IBGE-1 & 33.0 & 29.5 & 29.5 & 17.0 & 20.9 & 29.5 & 0.0 & & & & & & & & \\
\hline Musa & 23.3 & 26.9 & 20.9 & 20.9 & 17.0 & 20.9 & 20.9 & 0.0 & & & & & & & \\
\hline $\begin{array}{l}\text { Mushkan- } \\
340\end{array}$ & 26.9 & 24.1 & 24.1 & 29.5 & 20.9 & 24.1 & 29.5 & 26.9 & 0.0 & & & & & & \\
\hline IIRI-Pak & 35.6 & 31.9 & 31.9 & 31.9 & 24.1 & 31.9 & 26.9 & 29.5 & 12.0 & 0.0 & & & & & \\
\hline JP-5 & 35.6 & 31.9 & 31.9 & 31.9 & 24.1 & 31.9 & 26.9 & 29.5 & 12.0 & 0.0 & 0.0 & & & & \\
\hline Calmochi & 33.0 & 29.1 & 29.1 & 28.6 & 20.3 & 29.1 & 23.0 & 31.1 & 17.1 & 12.1 & 12.1 & 0.0 & & & \\
\hline IBGE-3 & 26.9 & 22.6 & 26.4 & 29.0 & 22.6 & 26.4 & 32.0 & 29.0 & 1.2 & 13.5 & 13.5 & 19.1 & 0.0 & & \\
\hline FM & 42.6 & 40.0 & 43.4 & 43.4 & 38.1 & 43.4 & 40.0 & 45.1 & 20.9 & 17.0 & 17.0 & 21.5 & 24.1 & 0.0 & \\
\hline Sug-Desi & 42.6 & 31.9 & 36.1 & 26.9 & 29.5 & 36.1 & 20.9 & 29.5 & 20.9 & 17.0 & 17.0 & 20.3 & 22.6 & 24.1 & 0.1 \\
\hline
\end{tabular}

\section{Discussion}

The development of a small number of standards, short duration, fertilizer responsive elite varieties of rice, because of the utilization of high yielding genotypes in a breeding program, has led to genetic erosion and, consequently, a remarkable loss of traditional heterogeneous cultivars (Hamid et al. 2015; Jones et al. 2008). For the development of a diverse population structure of rice, it is important to explore the genetic diversity within the population and among populations. The utilization of genetically diverse parents in the breeding program has the potential to develop varieties with higher yields per unit area (Roy et al. 2015). The study of genetic diversity based on phenotypic diversity is the primary step for the evaluation of germplasm (Nawaz et al. 2015). The major aim of studying genetic diversity and the identification of a certain valuable trait is to enhance the grain production of a particular crop. A lot of work has been done on agro-morphological characterization that has led to the identification of phenotypic variability in rice (Moukoumbi et al. 2011). In the present study, eight exotic and seven local rice genotypes have shown a significant diversity in both quantitative and qualitative traits, including plant height, days to maturity, panicle length, fertility factor, 1000 grain weight, and seed mineral content.

To measure the contribution and importance of each trait to the total variance, the Principal Component Analysis (PCA) is very useful. It can be applied to evaluate the independent impact of a specific trait on the total variation, while each coefficient of proper vectors identifies the degree of contribution of each original trait to which each principal component is related. They will be more effective in discriminating between genotypes when the value of coefficients is higher, irrespective of the direction, whether negative or positive (Vishnu et al. 2014). In the present study, PCA for the first two principal components has shown a total variation of $74.13 \%$ (Fig. 4). The first and second components factor (F1) and factor (F2) were considered which is $54.94 \%$ and $19.19 \%$ of total variations respectively. Except for days to maturity, all the traits vary together according to PCA1. According to PCA2, other traits such as plant height, number of productive tillers, and panicle length vary.

Molecular characterization of germplasm is important both for the protection of species and for the improvement of the crop (Ludivine et al. 2015). Previously, various classical and molecular markers have been used to provide a comparatively unbiased estimate of genetic diversity and efficiently link phenotypic and genotypic variations in plants. These markers include (1) biochemical markers (allozymes and other protein markers), (2) morphological markers, and (3) genetic or molecular markers (DNA markers) (Wijerathna 2015). Genetic markers are further categorized as (i) single nucleotide polymorphisms (SNPs) based on genome sequencing, (ii) PCR-based markers, i.e. random amplification of polymorphic DNAs (RAPDs), amplified fragment length polymorphisms (AFLPs), simple sequence repeats (SSRs), or microsatellites, inter simple sequence repeats (ISSRs) and (iii) Restriction fragment length polymorphisms (RFLPs) (Rajwant et al. 2011; Varshney et al., 2014). Genetic markers improve and speed up the plant breeding program by genome-wide association mapping and indirect selection linked to both simple and quantitative traits of interest (Heiba et al. 2016). Various types of molecular markers are available and used for genetic diversity analysis, where each type differs in genome abundance, genome coverage, expression/inheritance, and level of polymorphism (Nguyen et al. 2015). Microsatellite or SSR markers are the most used genetic markers that show a high level of polymorphism as compared to other markers and are preferred in almost all aspects of genetic research and breeding in most plant species (Kashiani et al. 2012). Furthermore, microsatellite markers are more abundant, ubiquitous in presence, hypervariable in nature, highly reproducible, require low amounts of DNA, easy to apply, have a low cost, less laborious, can be exchanged between laboratories, transferable between populations, and exhibit a high level of polymorphism even between closely related genotypes (Senan et al. 2014). The use of SSR or microsatellite markers for genome-wide association mapping, genetic variability, and species identification in rice and 
many other crop plants has been previously reported (Babak et al., 2015; Brondani et al. 2006; Jayamani et al. 2007; Khatab et al. 2015; Madhav et al. 2015; Molla et al. 2008). In this study, 5 SSR loci were assessed to find out the genetic diversity in 8 exotic and 7 local varieties. RM341 was the most effective marker, which produced the highest number, i.e. 4 polymorphic alleles, whereas RM259 gave the least number of polymorphic alleles. The polymorphism observed for all 5 SSR markers used, was $100 \%$. The average PIC value ranged from 0.39 to 0.91 . in addition, Wang et al. (2013) reported the same results in previous studies, and as a result, the PIC value ranged from 0.24 to 0.92 for 47 SSR markers, with an average of 0.52 . The number of band patterns observed in this study corresponded well with a previous study by Hassan et al. (2012). The PIC value represents information about a marker, allele frequency, and variety diversity (Sajib et al. 2012). The high PIC value and greater allele frequencies, in contrast with previous studies, support the idea that the genotype contains unique variations. The UPGMA cluster analysis separated the 15 rice genotypes into 3 main groups based on $32.5 \%$ similarities and the highest genetic distance (45.1\%) was observed between two genotypes (Fakhre-e-Malakand and Musa) having different geographical origins.

\section{Conclusion}

Based on quantitative morphological traits, the local and exotic genotypes were well separated into three clusters, where all the genotypes of European origin were grouped into a separate cluster. Based on molecular marker assessment, all the genotypes of rice were divided into three main groups at $32.5 \%$ similarities, where maximum genetic distances were noted for genotype, Fakhre-e-Malakand and Musa having a different origin, while minimum genetic distance was shown by genotype, Marte and Onice, from the same origin. Furthermore, there was no genetic distance between genotype Marte and Brio, having the same origin. The SSR markers used in this study were all polymorphic and amplified 14 alleles with variable allelic frequencies.RM 520 was highly informative with a PIC value of 0.91. The highest number of alleles, i.e. 4 alleles was obtained for RM 341. Evaluation of local and exotic rice genotypes at different locations under variable climatic conditions is recommended for better exploitation of germplasm. The exotic genotypes can be checked for cooking and taste qualities if these qualities have to be introgressed into the local varieties to improve the seed quality. The narrow genetic base of local rice cultivars is probably because of high selection pressure for good grain quality and repeated use of the same origin parents in the breeding program, resulting in significant genetic erosion of the local rice gene pool. It is recommended that representative exotic varieties having better traits should be chosen for inclusion in breeding programs aimed at varietal improvement.

\section{Declarations}

\section{Ethics approval}

This article does not contain any studies with human participants or animals performed by any of the authors.

\section{Consent to participate}

Not applicable

\section{Consent for publication}

Not applicable

\section{Availability of data and material}

Not applicable

\section{Conflicts of interest/Competing interests}

The authors declare that they have no conflict of interests.

\section{Acknowledgement}

Not applicable

\section{Authors' contributions}

SM, IUD, IU, AB, MNK, SS, AR: conceived and designed the experiments, SM, IUD, IU, AB, MNK, SS, AR: performed the experiments, SM, IUD, IU, AB, MNK, SS, AR: analyzed the data, SM, IUD, IU, AB, MNK, SS, AR: contributed to materials, tools, and wrote the manuscript, HIM: reviewed and editing the manuscript.

\section{Funding}

Not applicable

\section{References}

1. Akkaya MS, Shoemaker RC, Specht JE, Bhagwat AA, Cregan PB (1995) Integration of simple sequence repeat DNA markers into a soybean linkage map. Crop Sci 35(5): 1439-1445.

2. Ashry NA, Ghonaim MM, Mohamed HI, Mogazy AM (2018) Physiological and molecular genetic studies on two elicitors for improving the tolerance of six Egyptian soybean cultivars to cotton leaf worm. Plant Physiol Biochem 130: 224-234.

3. Babu PD, Subhasree R, Bhakyaraj R, Vidhyalakshmi R (2009) Brown rice-beyond the color reviving a lost health food-a review. Magnesium 187(13-10). 
4. Benton Jones Jr J (1991) Plant tissue analysis in micronutrients. Micronutrients in Agri 4: 477-521.

5. Bryan G, Collins A, Stephenson P, Orry A, Smith J, Gale M (1997) Isolation and characterisation of microsatellites from hexaploid bread wheat. Theor Appl Gene 94(5): 557-563.

6. Brondani C, Borba TCO, Rangel PHN, Brondani RPV (2006) Determination of genetic variability of traditional varieties of Brazilian rice using microsatellite markers. Gene Mol Biol 29(4): 676-684.

7. Chin E, Shu H, Smith J, Senior M (1996) Maize simple repetitive DNA sequences: abundance and allele variation. Genome 39(5): 866-873.

8. Cregan P, Jarvik T, Bush A, Shoemaker R, Lark K, Kahler A, Kaya N, VanToai T, Lohnes D, Chung J (1999) An integrated genetic linkage map of the soybean genome. Crop Sci 39(5): 1464-1490.

9. Chang TT (1976) The origin, evalution, cultivation, dissemination and diversification of Asian and African rices. Euphtica 25(1): 425-441

10. Chakravarthi BK, Naravaneni R (2006) SSR marker based DNA fingerprinting and diversity study in rice (Oryza sativa. L). African J Biotechnol 5(9).

11. Chuan-Guang L, ZHANG GQ (2010) Genetic Diversity Revealed by SSR Markers and Temporal Trends of Major Commercial Inbred Indica Rice Cultivars in South China in 1949-2005. Acta Agron Sinica 36(11): 1843-1852.

12. Cirillo A, Del Gaudio S, Di Bernardo G, Galderisi U, Cascino A, Cipollaro M (2009) Molecular characterization of Italian rice cultivars. European Food Res Technol 228(6): 875-881.

13. Doyle JJ, Doyle JL (1987) A rapid DNA isolation procedure for small quantities of fresh leaf tissue. Phytochem Bull 19: 11-15.

14. Dib C, Fauré S, Fizames C, Samson D, Drouot N, Vignal A, Millasseau P, Marc S, Kazan J, Seboun E (1996) A comprehensive genetic map of the human genome based on 5,264 microsatellites. Nature 380(6570): 152-154.

15. Garris AJ, Tai TH, Coburn J, Kresovich S, McCouch S (2005) Genetic structure and diversity in Oryza sativa L. Genetics 169(3): 1631-1638.

16. Ghonaim MM, Mohamed HI, Omran AAA (2021) Evaluation of wheat salt stress tolerance using physiological parameters and retrotransposon-based markers. Genet Resour Crop Evol 68: 227-242.

17. Gregorio GB, Senadhira D, Htut H, Graham RD (2000) Breeding for trace mineral density in rice. Food and Nutri Bull 21(4): $382-386$.

18. Horst L, Wenzel G (2007) Molecular marker systems in plant breeding and crop improvement: edn. Springer Science \& Business Media.

19. Hamid A, Ullah MJ, Haque MM, Mollah MFH, Rahman MM (2015). Improving grain yield of indigenous rice in tidal floodplain of southern bangladesh: effect of seedling age and transplanting method. Agri Sci 6(12): 1538.

20. Heiba S, El-Mouhamady AA, Eldessouky SEl, Ali HBM, Elewa TA (2016) Study the genetic variations related to the resistance of heavy metals toxicity in some rice genotypes using RAPD markers. Int J Curr Microbiol App Sci 5(1): 174-189.

21. Hong NT, Tuyen VTM, Hue NT, Trang TTT, Ham LH (2015) Genetic variability analysis in rice mutant lines from gamma rays radiation using agromorphological and SSR markers. J Agri Technol 11(8): 1793-1802.

22. Junaid NAAM, Ali A (2015) Economic analysis based on benefit cost ratio approach for rice varieties of malakand division. Economic Anal 6(19).

23. Jarne P, Lagoda PJ (1996) Microsatellites, from molecules to populations and back. Trends Ecol Evol 11(10): 424-429.

24. Jayamani P, Negrão S, Martins M, Maçãs B, Oliveira MM (2007) Genetic relatedness of Portuguese rice accessions from diverse origins as assessed by microsatellite markers. Crop Sci 47(2): 879-884.

25. Jones H, Lister DL, Bower MA, Leigh FJ, Smith LM, Jones MK (2008) Approaches and constraints of using existing landrace and extant plant material to understand agricultural spread in prehistory. Plant Gene Reso 6(2): 98-112.

26. Kobayashi M, Kawakita K, Maeshima M, Doke N, Yoshioka H (2006) Subcellular localization of Strboh proteins and NADPH-dependent generating activity in potato tuber tissues. J Exp Bot 57(6): 1373-1379.

27. Khush GS (1997) Origin, dispersal, cultivation and variation of rice. Plant Mol Biol 35(1-2): 25-34.

28. Kunusoth K, Vadivel K, Sundaram RM, Sultana R, Rajendrakumar P, Maganti S, Subbarao LV, Chin-Wo SR (2015) Assessment of genetic diversity of elite indian rice varieties using agro-morphological traits and SSR Markers. J Exp Agri Inter 6(6): 384-401.

29. Kalia RK, Rai MK, Kalia S, Singh R, Dhawan AK (2011) Microsatellite markers: an overview of the recent progress in plants. Euphytica 177(3): 309-334.

30. Kashiani P, Saleh G, Panandam JM, Abdullah NAP, Selamat A (2012) Molecular characterization of tropical sweet corn inbred lines using microsatellite markers. Maydica 57(2): 154-163.

31. Khatab IA, Farid MA, Kumamaru T (2016) Genetic diversity associated with heading date in some rice (Oryza sativa L.) genotypes using microsatellite markers. J Environ Agri Sci 6: 58-63.

32. Latif M, Yusop MR, Rahman MM, Talukdar MB (2011) Microsatellite and minisatellite markers based DNA fingerprinting and genetic diversity of blast and ufra resistant genotypes. Comptes Rendus Biol 334(4): 282-289.

33. Lassois L, Denancé C, Ravon E, Guyader A, Guisnel R, Hibrand-Saint-Oyant L, Poncet C, Lasserre-Zuber P, Feugey L, Durel C (2016) Genetic diversity, population structure, parentage analysis, and construction of core collections in the French apple germplasm based on SSR markers. Plant Mol Biol Reporter 34(4): 827-844.

34. Lloyd B, Siebenmorgen T, Beers K (2000) Effects of commercial processing on antioxidants in rice bran. Cereal Chem 77(5): 551-555.

35. Liakat AM, McClung AM, Jia MH, Kimball JA, McCouch SR, Georgia CE (2011) A rice diversity panel evaluated for genetic and agro-morphological diversity between subpopulations and its geographic distribution. Crop Sci 51(5): 20212035.

36. Mandel JR, Dechaine JM, Marek LF, Burke JM (2011) Genetic diversity and population structure in cultivated sunflower and a comparison to its wild progenitor, Helianthus annuus L. Theor Appl Genet 123: 693-704.

37. Memon NA (2013) Rice: Important cash crop of Pakistan. Pak Food J 21-23.

Page $10 / 15$ 
38. Milbourne D, Meyer R, Collins A, Ramsay L, Gebhardt C, Waugh R (1998) Isolation, characterisation and mapping of simple sequence repeat loci in potato. Mol General Gene MGG 259(3): 233-245.

39. Madhav M, Siva Raju K, Gaikwad K, Vishalakshi B, Murthy TGK, Umakanth (2015) Development of new set of microsatellite markers in cultivated tobacco and their transferability in other Nicotiana spp. Mol Plant Breed 6(16): 1-13.

40. Molla KA, Debnath AB, Ganie SA, Mondal TK (2015) Identification and analysis of novel salt responsive candidate gene based SSRs (cgSSRs) from rice (Oryza sativa L.). BMC Plant Biol 15(1): 122.

41. Mohamed HI, Abdel-Hamid AME (2013) Molecular and biochemical studies for heat tolerance on four cotton genotypes (Gossypium hirsutum L.). Romanian Biotechnol Lett 18(6): 7223-7231.

42. Mohamed HI, Abd-El Hameed AG (2014) Molecular and biochemical markers of some Vicia faba L. genotype in response to storage insect pests infestation. J Plant Inter 9(1): 618-626.

43. Mohamed HI, Akladious SA, Ashry NA (2018) Evaluation of six soybean genotypes using retroelements and some physiological parameters under water stress. Gesunde Pflanzen 70: 205-215

44. Mohamed HI, Ashry NA, Ghonaim MM (2019) Physiological analysis for heat shock induced biochemical (responsive) compounds and molecular characterizations of ESTs expressed for heat tolerance in some Egyptian maize hybrids. Gesunde Pflanzen 71: 213-222.

45. Moukoumbi Y, Sié M, Vodouhe R, N'dri B, Toulou B, Ogunbayo SA, Ahanchede A (2011) Assessing phenotypic diversity of interspecific rice varieties using agro-morphological characterization. J Plant Breed Crop Sci 3(5): 74-86.

46. Nawaz S, Chaudry Z, Bibi A, Jan SA, Bibi K (2015) Agro-morphological and molecular characterization of local tomato cultivars grown in pakhal region of Pakistan using RAPD markers. Middle-East J Sci 23(5):856-860.

47. Oka HI (1988) Origin of Cultivated Rice. Development in Crop Science 14: 1-254.

48. Pervaiz ZH, Rabbani MA, Shinwari ZK, Masood MS, Malik SA (2010) Assessment of genetic variability in rice (Oryza sativa L.) germplasm from Pakistan using RAPD markers. Pak J Bot 42(5): 3369-3376.

49. Powell W, Machray GC, Provan J 1996) Polymorphism revealed by simple sequence repeats. Trends Plant Scie 1(7): $215-222$.

50. Rabbani MA, Pervaiz ZH, Masood MS (2008) Genetic diversity analysis of traditional and improved cultivars of Pakistani rice (Oryza sativa L.) using RAPD markers. Electronic J Biotechnol 11(3): 52-61.

51. Ram, SG, Thiruvengadam V, Vinod KK (2007) Genetic diversity among cultivars, landraces and wild relatives of rice as revealed by microsatellite markers. J Appl Gene 48(4): 337-345.

52. Röder MS, Korzun V, Wendehake K, Plaschke J, Tixier MH, Leroy P, Ganal MW (1998) A microsatellite map of wheat. Genetics 149(4): $2007-2023$.

53. Rabiei B, Kordrostami M, Sabouri A, Sabouri H (2015) Identification of QTLs for yield related traits in Indica type rice using SSR and AFLP markers. Agric Conspectus Sci 80(2): 91-99.

54. Roy P, Hasan MA, Rasul M, Hossain M (2015) Seed culture of aromatic rice varieties under salt stress. American J Biol Life Sci 3(6): 260.

55. Senan S, Kizhakayil D, Sasikumar B, Sheeja TE (2014) Methods for development of microsatellite markers: an overview. Notulae Sci Biol 6(1): 1-13.

56. Salgotra R, Gupta B, Bhat JA, Sharma S (2015) Genetic diversity and population structure of Basmati rice (Oryza sativa L.) germplasm collected from North Western Himalayas using trait linked SSR markers. Plos One 10(7):131-858.

57. Sarao NK, Vikal Y, Singh K, Joshi MA, Sharma R (2010) SSR marker-based DNA fingerprinting and cultivar identification of rice (Oryza sativa L.) in Punjab state of India. Plant Gene Reso 8(1): 42-44.

58. Sasaki T, Burr B (2000) International Rice Genome Sequencing Project: the effort to completely sequence the rice genome. Current Opinion Plant Biol 3(2): 138-142.

59. Shah SM, Naveed SA, Arif M (2013) Genetic diversity in basmati and non-basmati $\quad$ rice varieties based on microsatellite markers. Pak J Bot 45(S1): 423-431.

60. Shah SMA, Rahman H, Abbasi FM, Rabbani MA, Khan IA, Shinwari ZK (2011) Inter specific variation of total seed protein in wild rice germplasm using SDSPAGE. Pa J Bot 43(4): 2147-2152.

61. Shih FF (2003) An update on the processing of high-protein rice products. Food Nahrung 47(6): 420-424.

62. Sajib AM, Hossain M, Mosnaz A, Hossain H, Islam M, Ali M, Prodhan SH (2012) SSR marker-based molecular characterization and genetic diversity analysis of aromatic landreces of rice (Oryza sativa L.). J BioSci Biotechnol 1(2).

63. Taramino G, Tingey S (1996) Simple sequence repeats for germplasm analysis and mapping in maize. Genome 39(2): $277-287$.

64. Varshney RK, Terauchi R, McCouch SR (2014) Harvesting the promising fruits of genomics: applying genome sequencing technologies to crop breeding. PLoS Biol 12(6).

65. Vaughan DA, Morishima H, Kadowaki K (2003) Diversity in the Oryza genus. Current Opinion Plant Biol 6(2): 139-146.

66. Varshney RK, Chabane K, Hendre PS, Aggarwal RK, Graner A (2007) Comparative assessment of EST-SSR, EST-SNP and AFLP markers for evaluation of genetic diversity and conservation of genetic resources using wild, cultivated and elite barleys. Plant Sci 173(6): 638-649.

67. Wijerathna Y (2015) Marker assisted selection: biotechnology tool for rice molecular breeding. Advances Crop Sci Technol: 1-4.

68. Yamanaka S, Nakamura I, Watanabe KN, Sato YI (2004) Identification of SNPs in the Waxy gene among glutinous rice cultivars and their evolutionary significance during the domestication process of rice.Theor Appl Gene 108: 1200-1204.

69. Ye-Yun X, Zhan Z, Yi-Ping X, Long-Ping Y (2005) Identification and purity test of super hybrid rice with SSR molecular markers. Rice Sci 12 (1): 7-12. 
Figures

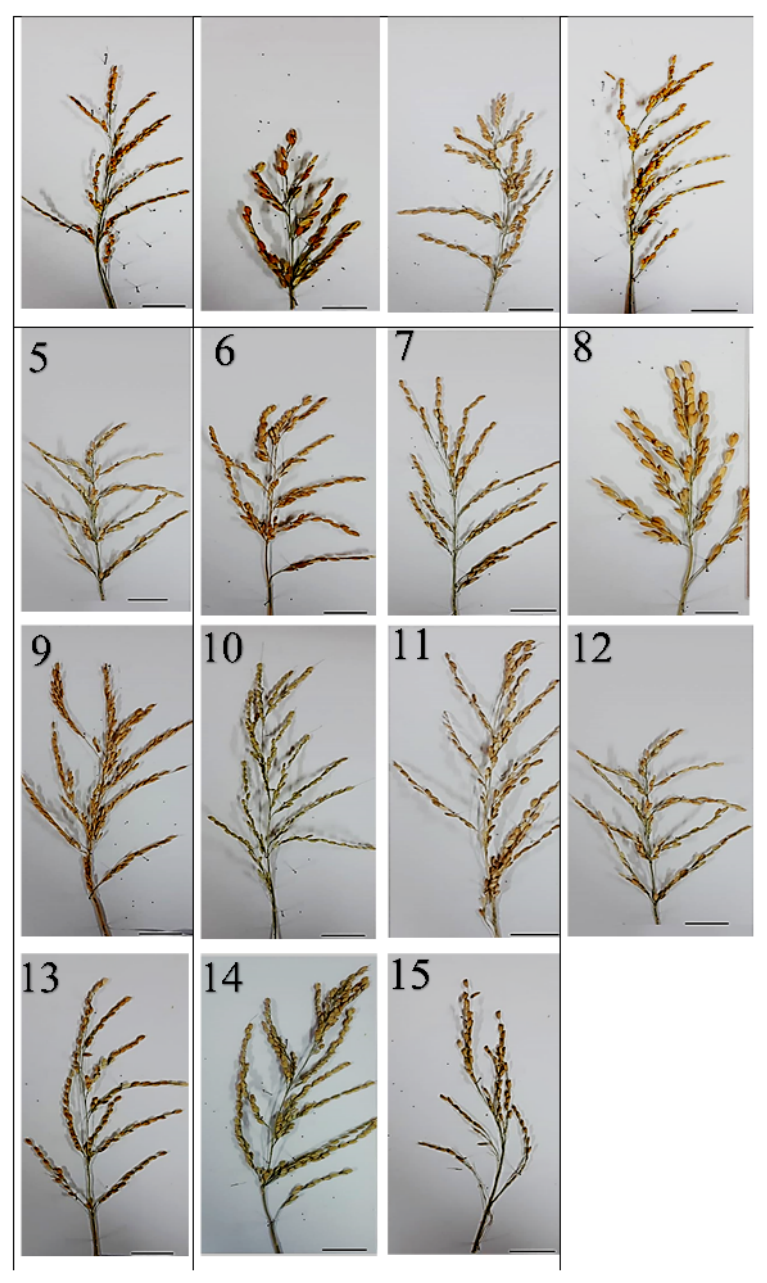

\section{Figure 1}

Panicle length of rice germplasm. 1. Swati-2014; 2. Originario; 3. Brio; 4. Ibge-2; 5. Onice; 6. Marte; 7. Ibge1; 8. Musa; 9. Mushkan; 10. Irri-Pak; 11. Begami; 12. Calmochi; 13. Ibge-3; 14. FM, 15. Sug-Dasi/ DR-83. 

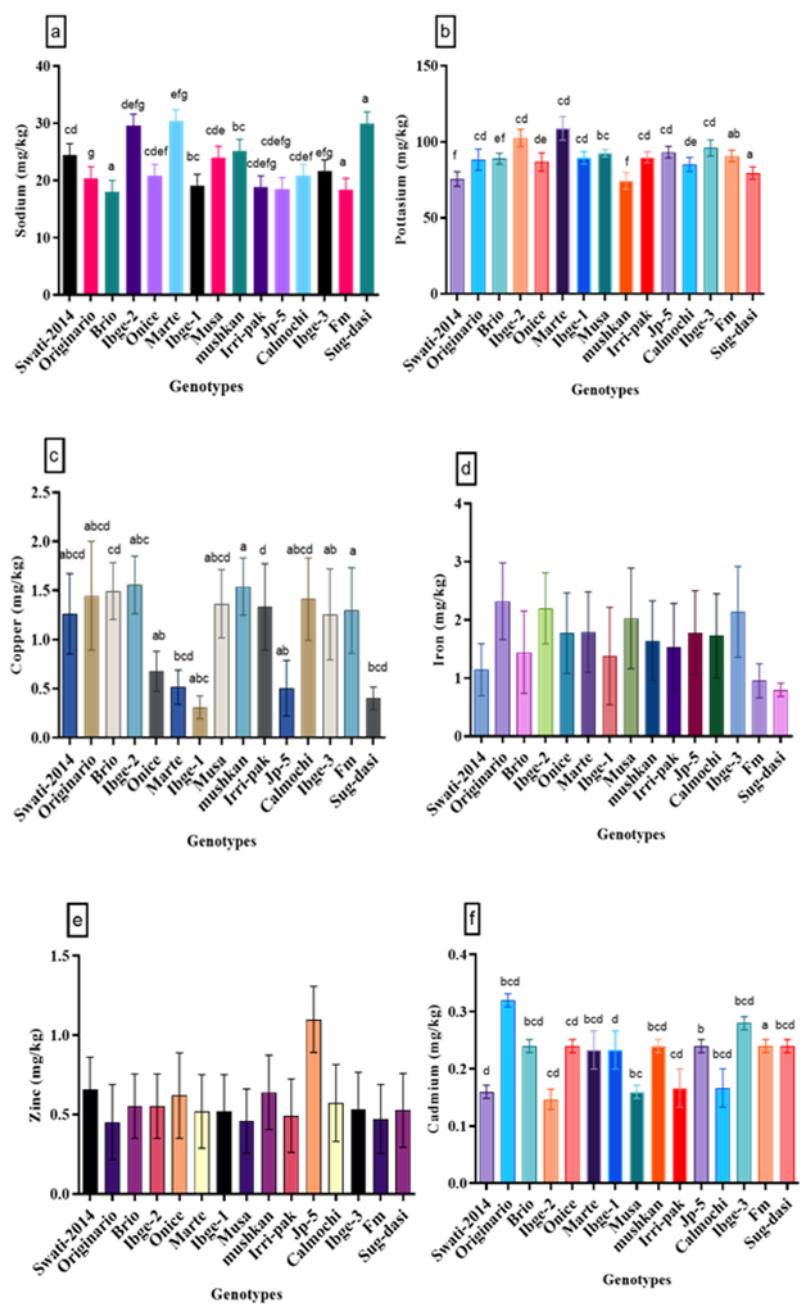

Figure 2

Quality attributes of local and exotic genotypes of rice

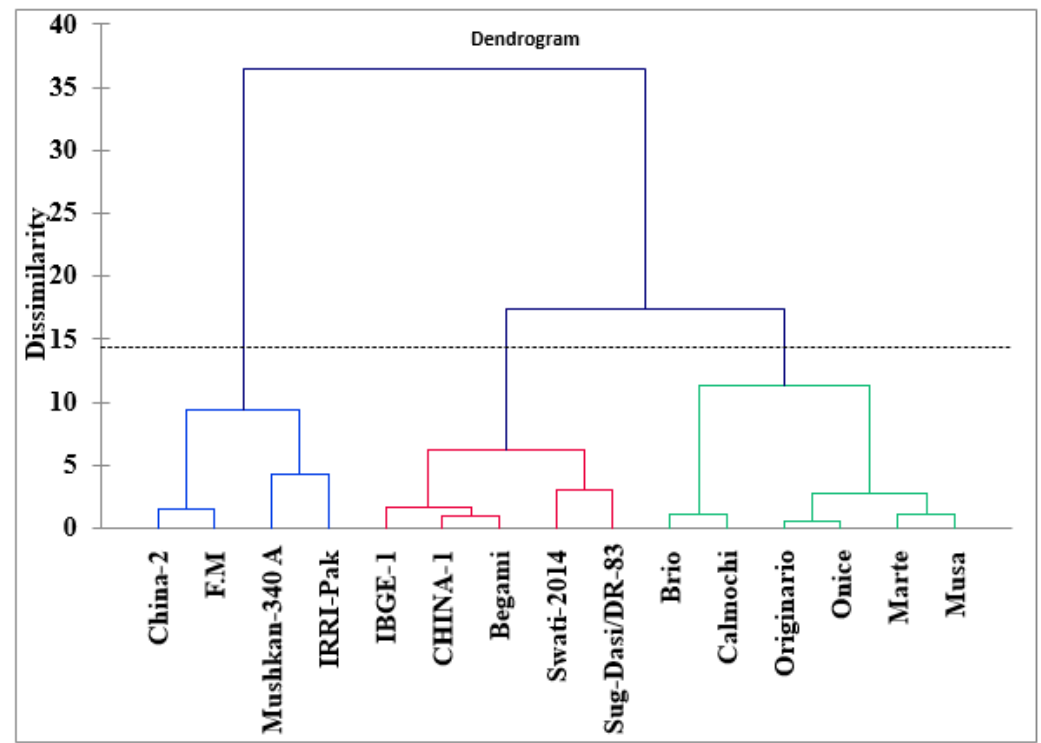

Figure 3

Morphological Dendrogram of 15 rice genotypes 


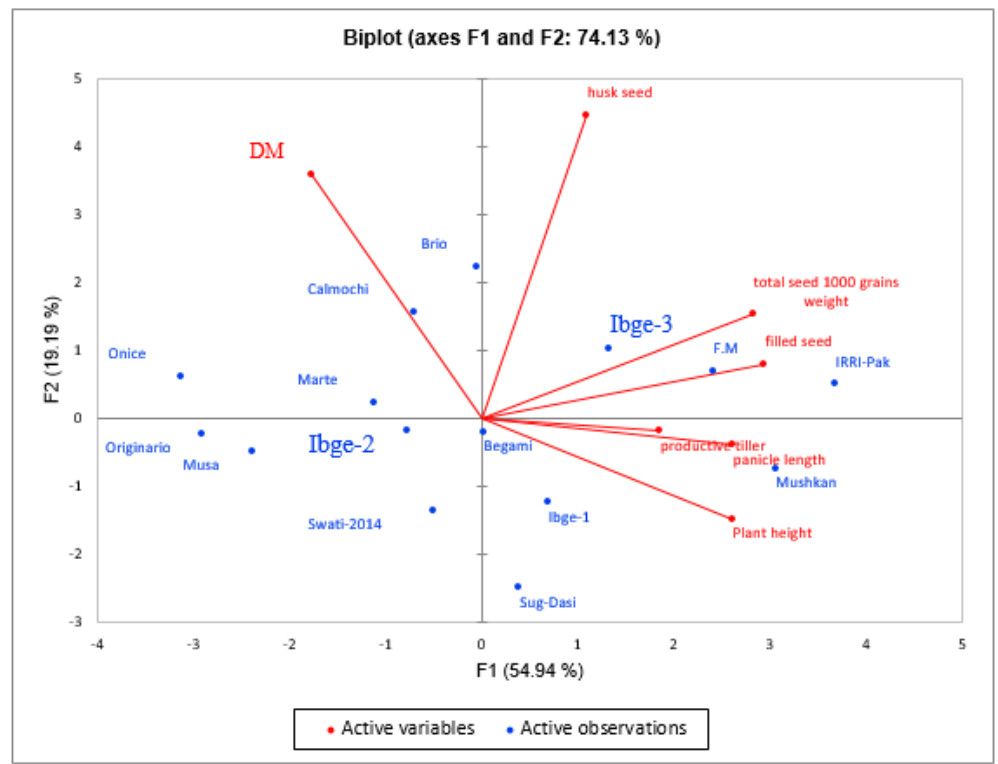

Figure 4

Principle component analysis (PCA), based on agro-morphological traits.

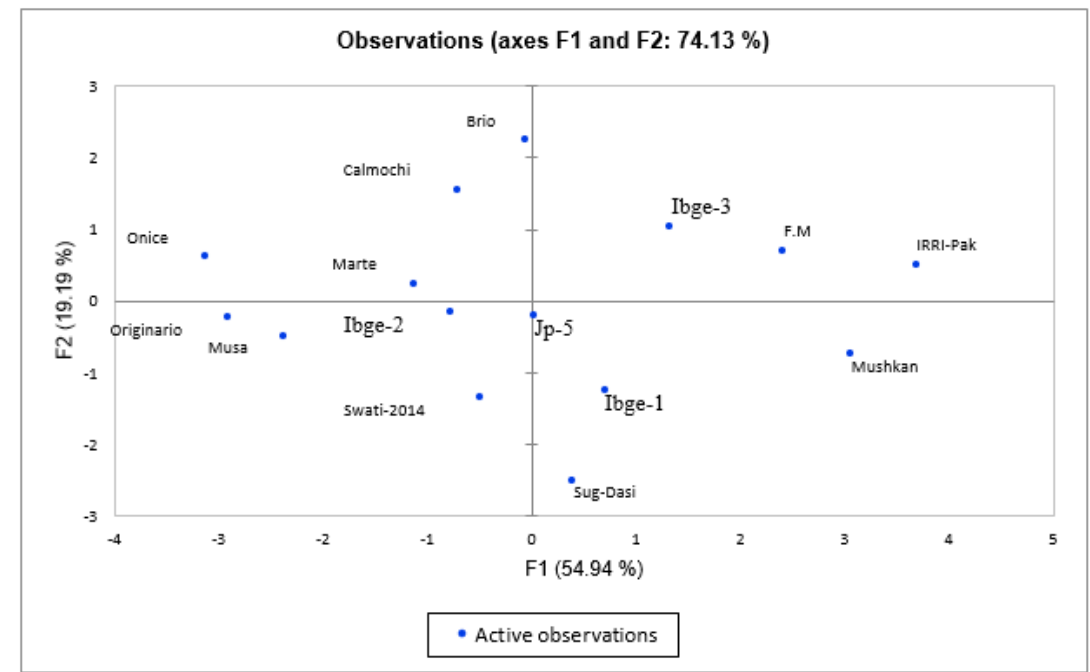

Figure 5

PCA scattered plot constructed based on agro-morphological traits 


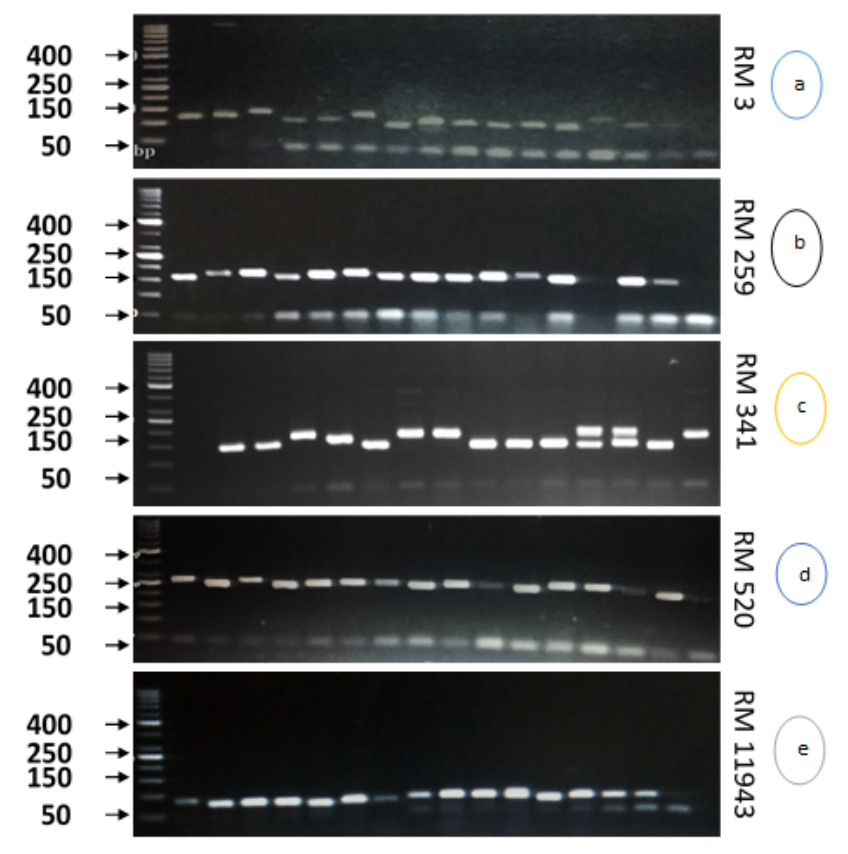

Figure 6

PCR amplification profile of SSR marker (a) RM3 (b) RM259 (c) RM 341 (d) RM 520 (e) RM 11943. M represents 50 Kb ladder; 1. Swati-2014; 2. Originario; 3. Brio; 4. Ibge-2; 5. Onice; 6. Marte; 7. Ibge1; 8. Musa; 9. Mushkan; 10. Irri-Pak; 11. Begami; 12. Calmochi; 13. Ibge-3; 14. FM and 15. Sug-Dasi/ DR-83. PCR product was separated on $2 \%$ agarose gel.

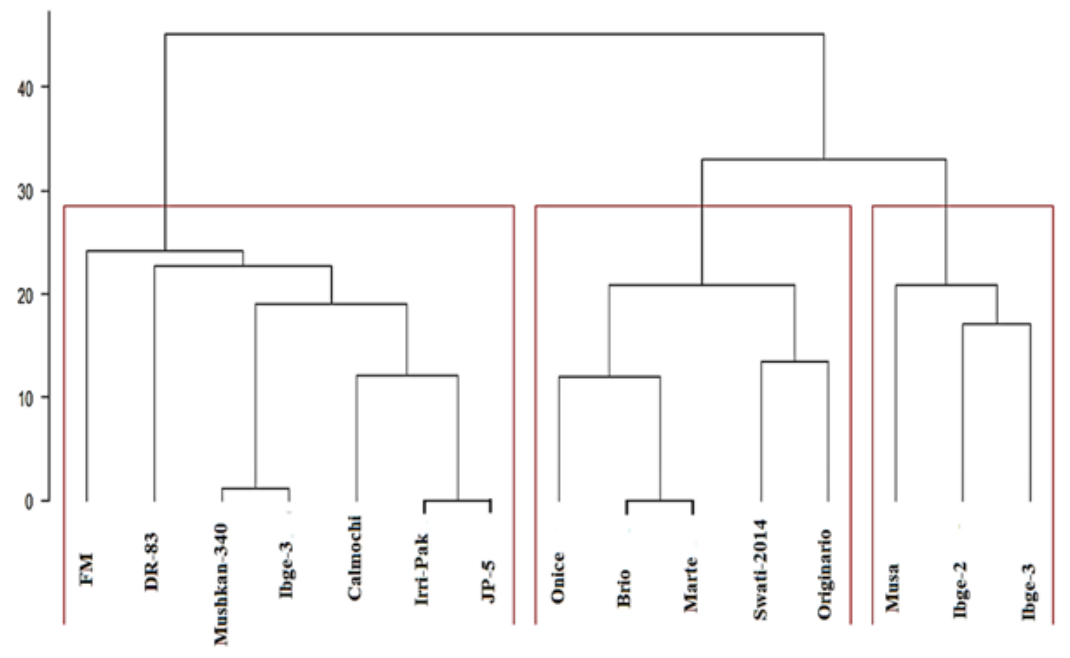

Figure 7

Dendrogram constructed for 15 rice germplasm by Pop-gene version 3.5 based on genetic similarities using five set of SSR primers. 